\title{
OPEN DEFECATION FREE IN KARTIASA VILLAGE IN THE ERA OF REGIONAL AUTONOMY: IMPLEMENTATION AND BARRIERS
}

\author{
Tamrin Muchsin \\ Fakultas Syariah, Institut Agama Islam Sultan Muhammad Syafiuddin Sambas \\ Jl. Raya Sejangkung, Sambas Kalimantan Barat \\ e-mail: tamrinmuchsin69@gmail.com \\ Sri Sudono Saliro \\ Fakultas Syariah, Institut Agama Islam Sultan Muhammad Syafiuddin Sambas \\ Jl. Raya Sejangkung, Sambas Kalimantan Barat \\ e-mail: srisudonosalirofh@gmail.com
}

\begin{abstract}
Abstrak: Tujuan penelitian ini untuk menganalisis keterlibatan Pemerintah Desa Kartiasa dalam melaksanakan salah satu program Sanitasi Total Berbasis Masyarakat (STBM), yaitu Open Defecation Free (ODF) pada era otonomi daerah saat ini. Penelitian ini berfokus pada bagaimana bentuk keterlibatan Pemerintah Desa ODF pada wilayah Kabupaten Sambas, yaitu Desa Kartiasa, serta faktor penghambat pelaksanaan program ODF. Tulisan penelitian ini bersifat empiris, dan untuk memperoleh data melakukan obesevasi dan wawancara. Hasil penelitian ditemukan bahwa Pemerintah Desa Kartiasa dalam melaksanakan program ODF berdasarkan pada Surat Edaran Bupati Sambas Nomor 440/16/Dinkes tentang Pelaksanaan Program Sanitasi Total Berbasis Masyarakat. Faktor penghambat pelaksanaan ODF oleh Pemerintah Desa Kartiasa yaitu rendahnya kesadaran masyarakat untuk hidup bersih, rendahnya pengetahuan masyarakat akan nilai kesehatan, tidak ada peraturan desa, terbatasnya sarana dan prasarana, dan tidak ada pengawasan
\end{abstract}

Kata Kunci: Pemerintah Desa, Open Defecation Free, Otonomi Daerah

\begin{abstract}
The purpose of this study was to analyze the involvement of the village government in implementing one of the Community-Based Total Sanitation (STBM) programs, namely Open Defecation Free (ODF) in the current era of regional autonomy. This research focuses on how the form of ODF Village Government involvement in the Sambas Regency area, namely Kartiasa Village, as well as the inhibiting factors for the implementation of the ODF program. The writing of this research is empirical, and to obtain data, we conduct observations and interviews. The results showed that the Kartiasa Village Government in implementing the ODF program was based on the Sambas Regent Circular Number 440/16/Dinkes concerning the Implementation of the Community-Based Total Sanitation Program. The inhibiting factors for the implementation of ODF by the Kartiasa Village Government are low community awareness to live clean, low community knowledge of the value of health, no village regulations, limited facilities and infrastructure, and no supervision
\end{abstract}

Keywords: Village Government, Open Defecation Free, Regional Autonomy. 


\section{INTRODUCTION}

A very basic human need is health. This is an important element of achieving general welfare as stipulated in the 1945 Constitution, which is then manifested in the form of sustainable national development. ${ }^{1}$ Article $28 \mathrm{H}$ paragraph (1) states that everyone has the right to live in physical and spiritual prosperity, to have a place to live, and to have a good and healthy living environment and has the right to receive health services. ${ }^{2}$

However, health problems that often occur in Indonesia, such as drinking water, hygiene and sanitation are still very large. Sanitation means community behavior as an effort to maintain and protect the cleanliness of the environment. Implementation of the Community-Based Total Sanitation Program (STBM), as described in the 2015-2019 National Medium-Term Development Plan (RPJMN) requires that every level of government, starting from the lowest level, namely Villages, Districts, Districts and

\footnotetext{
1 Tatiek Setyaningsih and Bayu Mitra Adhyatma Kusuma, "Mendobrak Keterbatasan Masyarakat: Mewujudkan Desa Open Defecate Free Di Kabupaten Banyuwangi Melalui Inovasi 'Pujasera,"' The Indonesian Journal of Public Administration Volume 2, no. 2 (Nopember 2016): 2.

2 Sekretariat Jenderal MPR RI 2018, “UndangUndang Dasar Negara Republik Indonesia Tahun 1945" (2018), Lihat Pasal 28H ayat (1).

3 Della Putri Arifianty, "Peran Pemerintah Lokal Dalam Peningkatan Sanitasi Lingkungan Masyarakat: Studi Tentang Keberhasilan Program Open Defecation Free (ODF) Di Kabupaten Bojonegoro," Jurnal Kebijakan Dan Manajemen Publik Volume 5, no. 3, September-Desember (2017): 1.
}

Provinces to implement the program. ${ }^{4}$ Then through the Regulation of the Minister of Health of the Republic of Indonesia Number 3 of 2014 concerning Community-Based Total Sanitation, the program has been designated as a national program and in its application it is handed over to regions to address sanitation problems in their respective regions.

The STBM program in the long term can encourage the realization of a healthy, independent and just society. ${ }^{5}$ Changes in behavior in STBM done through methods triggering encourage behavior change in target communities collectively and able to build sanitation facilities independently according to ability. ${ }^{6}$ The same statement was made by Sjafrizal, that the era of regional autonomy has become a regional development planning system, central government interference has decreased and regions are given greater authority to

4 Ditjen Kesehatan Masyarakat, Kementerian Kesehatan, Kebijakan Nasional Sanitasi Total Berbasis Masyarakat (STBM) (Jakarta: Disampaikan dalam Lokakarya Review STBM pada 24 Januari, 2019).

5 Maria Sophie Muaja, Odi Roni Pinontoan, and Oksfriani Jufri Sumampouw, "Peran Pemerintah Dalam Implementasi Program Sanitasi Total Berbasis Masyarakat Stop Buang Air Besar Sembarangan," Indonesian Journal of Public Health and Community Medicine Volume 1, no. 3 (July 2020): 28.

6 Kementerian Kesehatan, "Peraturan Menteri Kesehatan Republik Indonesia Nomor 3 Tahun 2014 Tentang Sanitasi Total Berbasis Masyarakat" (2014), Lihat Penjelasan. 
manage development in their respective regions. $^{7}$

In terms of sanitation, development is defined as the development of hygienic behavior in the community. The STBM program which seeks to create public awareness in terms of environmental health, the success of the STBM program is also certainly related to the role of the government and the community's response to the program. So actually the main purpose of a community-based or community-based development is related to community empowerment. According Mardikanto and Poerwoko, that the implications of a development strategy based on community (people centered development) always refers to the improvement, including improvements in the quality of human life, whether physical, mental, economic and socio-cultural her. ${ }^{8}$ Efforts to empower community behavior do not differentiate who will participate. The participation of the District/City Government, District level, and Village/Sub-district level has a major contribution in changing environmentally friendly community behavior so that the

\footnotetext{
${ }^{7}$ Sjafrizal, Perencanaan Pembangunan Daerab Dalam Era Otonomi (Jakarta: PT RajaGrafindo Persada, 2014), 110.

8 Mardikanto and Poerwoko, Pemberdayaan Masyarakat Dalam Perspektif Kebijakan Publik. (Bandung: Alfabeta, 2015), 109.

9 Mira Rosana, "Kebijakan Pembangunan Berkelanjutan Yang Berwawasan Lingkungan Di Indonesia," Jurnal KELOL A: Jurnal Ilmu Sosial Vol. 1 No. 1 (2018): 148.
}

goals of sustainable development can be achieved.

The concept of sustainable development can be interpreted as a process of change towards something better. The situation is better than the original state the purpose of the implementation of the development. ${ }^{9}$ Conceptually, sustainable development was identified as the ideal framework and strategic environmental management. ${ }^{10}$ There are 5 (five) pillars of STBM behavior that refer to an environmentally sound development attitude.

The STBM pillar as contained in Article 3 paragraph (2) of the Regulation of the Minister of Health Number 3 of 2014 concerning Community-Based Total Sanitation consists of the following behaviors:

\section{a. Stop Open Defecation;}

b. Wash Hands With Soap;

c. Household Drinking Water and Food Management;

d. Household Waste Protection; and

e. Household Liquid Waste Security. ${ }^{11}$

The results of preliminary observations made by researchers, found an interesting

\footnotetext{
${ }^{10}$ Yusriani Sapta Dewi, "Peran Perempuan Dalam Pembangunan Berkelanjutan," Jurnal Pendidikan Lingkungan Dan Pembangunan Berkelanjutan Vol. XII No. 02 (2011): 61.

11 Kementerian Kesehatan, Peraturan Menteri Kesehatan Republik Indonesia Nomor 3 Tahun 2014 Tentang Sanitasi Total Berbasis Masyarakat, Lihat Pasal 3 Ayat (2).
} 
thing, namely when Kartiasa Village was awarded as an Open Defecation Free Village (ODF) on Monday 28 April 2014, in which this ODF village was committed and consistent to: first, not defecating (BAB) anywhere; second, always keep the environment clean; and third, always have a clean and healthy lifestyle. ${ }^{12}$ The Head of Kartiasa Village (Edy Rakhman) explained that between 2014 and 2020 the problem of defecating in any place was still found, and this is a habit of bad community behavior. Defecating carelessly will have bad effects on health, such as hypertension, influenza, coughing, diarrhea and diabetes. ${ }^{13}$

Cultivate healthy defecation behavior can cut the flow of human fecal contamination as a source of disease on an ongoing basis. Civilizing activities of human behavior into one of sustainable human development agenda of concern for the central government or local governments. ${ }^{14}$ The participation of local governments in the implementation of these activities can be seen in the formation of a regional government task force, which

12 Wawancara dengan Bapak Edy Rakhman selaku Kepala Desa Kartiasa, tanggal 2 Juli, 2020.

13 Hadiati Sukma, Mursid, and Nurjazuli, "Hubungan Pengetahuan, Sikap BAB, Dan Kepemilikan Septic Tank Dengan Status ODF (Open Defecation Free) Di Kecamatan Candisari Kota Semarang," Jurnal Kesehatan Masyarakat Volume 6, no. Nomor 6, Oktober (2018): pp 143-149.

${ }^{14}$ Mickael B Hoelman and Sugeng Bahagijo, dkk, Sustainable Development Goals-SDGs (Panduan Untuke Pemerintah Daerah Kabupaten/Kota Dan Pemangku aims to encourage people to behave in stopping open defecation and having defecation facilities that meet national standards. ${ }^{15}$

In the context of accelerating access to sanitation in 2019 to achieve coverage of $100 \%$ drinking water, $0 \%$ slum areas and $100 \%$ access to sanitation, strategic steps are needed to increase community access to sustainable drinking water and sanitation through the implementation of the STBM national strategy as an approach to sanitation development in Indonesia. One of the main activities in the STBM approach is to create a village that is free from defecating in any place. Based on this, a Circular Letter of the Regent of Sambas Number 440/16 / Dinkes was issued regarding the Implementation of a Community-Based Total Sanitation Program. ${ }^{16}$

One of the mandates of the Sambas Regent Circular Number 440/16 / Dinkes concerning the Implementation of the Community-Based Total Sanitation Program, namely optimizing the role of the District and Village in

Kepentingan Daerah) (Jakarta Selatan: INFID Edisi Revisi, 2016), 12.

${ }^{15}$ UCLG, "UCLG and Global Taskforce Advocacy Pays off in SDGs Outcome Document 'Transforming Our World'. Http://Www.Uclg.Org/En/Media/News/Uclgand-Global- Taskforce-Advocacy-Pays-SDGsOutcome-Document-Transforming-OurWorld.," n.d., diakses tanggal 10 mei 2020.

16 "Surat Edaran Bupati Sambas Nomor 440/16/Dinkes Tentang Pelaksanaan Program Sanitasi Total Berbasis Masyarakat" (2018). 
achieving areas that are free from open defecation. Based on this mandate, the role of the village government, especially Kartiasa Village, which is an ODF village, is to implement changes in community behavior not to defecate openly. However, the observation find people who defecation by using a water close the disposal of the sludge directly on the river water Kartiasa.

Based on the explanation above, regarding the efforts to change the behavior of the Kartiasa community with hygienic principles, the aspect of government administration that interacts most with the community is the Kartiasa Village Government. The formulation of the legal issues that were examined is how the village government involvement in implementing Kartiasa open defecation free by Sambas Regent circular on the implementation of STBM ?. and what factors hampered the implementation of the STBM program ?.

\section{METHOD}

The discussion of this paper uses empirical legal research on the mandate of the Sambas Regent Circular Number

${ }^{17}$ Norman K. Denzin, Yvonna S. Lincoln (editor), and Dariyatno (penerjemah), Handbook of Qualitative Research (Edisi Ketiga) (Yogyakarta: Pustaka Pelajar, 2009), 507-508. Dalam buku Jamiat Akadol, Budaya Hukum Birokrasi Pelayanan Publik di Indonesia
440/16/Dinkes concerning the Implementation of Community-Based Total Sanitation Programs. The research location is in Kartiasa Village, Sambas District, Sambas Regency, West Kalimantan Province, Indonesia. The main data source in the research is the study of information, opinions and responses through interviews and direct observation with Kartiasa village government officials and the public. ${ }^{17}$ In addition, the supporting data sourced from documents, official reports and legislation, as well as researchers in determining the source data using purposive sampling. This sampling is based on the research objectives to be achieved. ${ }^{18}$

(Yogyakarta: Penerbit Deepublish Publisher, 2020), 39.

${ }^{18}$ M Atho Mudzhar, Pendekatan Studi Islam Dalam Teori Dan Praktek (Yogyakarta: Pustaka Pelajar, 1998), 70 . 


\section{RESULTS AND DISCUSSION}

\section{Brief Description of Kartiasa Village as ODF Village}

Sambas Regency is one of the Second Level Regions in the province of West Kalimantan. Sambas Regency has an area of $6,395.70 \mathrm{~km}^{2}$ or 639,570 ha $(4.36 \%$ of the area of West Kalimantan Province). It is a regency area located on the northernmost part of the west coast of West Kalimantan province. The length of the coast is \pm 128.5 $\mathrm{km}$ and the length of the state border is \pm $97 \mathrm{~km} .{ }^{19}$

In Sambas district there are 193 village, one of which is the village Kartiasa. The area of the village is approximately 2500 hectares. Declaration of Kartiasa Village as ODF Village on Monday, April 28 2014, with commitment and consistency to: first, not defecating in any place, second, always maintaining a clean environment and third, always having a clean and healthy lifestyle, then signed by the Head Hamlet, Head of Kartiasa Village and Head of Sambas District. This ODF Village declaration was based on the results of the verification which was carried out for 3 days, namely 25 to 27 April 2014.20

19 Badan Pusat Statistik Kabupaten Sambas, "Kabupaten Sambas dalam Angka 2020

${ }^{20}$ Profil Desa Kartiasa tahun 2019

21 Kementerian Kesehatan, Peraturan Menteri Kesehatan Republik Indonesia Nomor 3 Tahun

\section{STBM Program During Regional}

\section{Autonomy}

STBM approach is to change behavior and sanitary hygiene by empowering people by triggering. ${ }^{21}$ The approach through STBM is very suitable for the village government to change community behavior by encouraging changes in hygiene and sanitation behavior for individuals or communities on their own awareness by touching feelings, patterns of thought, behavior and habits of individuals or communities. This method is known as the triggering method.

Furthermore, basic sanitation is a basic effort in improving human health by providing a healthy environment that meets the health requirements. ${ }^{22}$ Basic sanitation efforts in the community include the provision of clean water, healthy latrines, waste management and sewerage. STBM fifth pillar is intended to break the chain of transmission of the disease and poisoning.

2014 Tentang Sanitasi Total Berbasis Masyarakat, Lihat Pasal 1 angka 1.

22 Almas Ghassani Celesta and Nurul Fitriyah, "Gambaran Sanitasi Dasar Di Desa Payaman, Kabupaten Bojonegoro Tahun 2016," Jurnal 
It is important to keep it from cross contamination and keep cleanliness. ${ }^{23}$

The role of the government bureaucracy is very broad considering that this role is limited to matters of a strategic nature. Especially regarding the aspects of the efficient, effective, fast and precise implementation of the bureaucracy in providing services to the community. To know a society, the point of view is its government. ${ }^{24}$ Meanwhile, according to Rasyid, community empowerment is actually a part of four government functions which are divided into four parts, namely service (public service), development (development), empowerment (empowering), and regulation (regulation). Government functions that are carried out at a certain time will reflect the quality of government itself. If the government then carries out its functions well, then the main tasks can be carried out properly such as services can produce justice, empowerment can lead to independence, and development that creates prosperity. ${ }^{25}$

Kesehatan Lingkungan Volume 11, no. 2. April (2019): 83, doi:10.20473/jkl.v11i2.2019.83-90.

${ }^{23}$ Zamia Floridiana, "Analisis Higiene Penjamah Makanan Dan Sanitasi Lingkungan Pada Industri Rumah Tangga Tahu Jombang 2018," Jurnal Kesehatan Lingkungan Volume 11, no. 1. Januari (2019): 78, doi:10.20473/jkl.v11i1.2019.75-82.

24 Robby Ahmadi, "Analisis Peran Pemerintah Pekon Dalam Pelaksanaan Pilar Pertama Program Sanitasi Total Berbasis Masyarakat Di Kabupaten Pringsewu (Studi Di Pekon Wonodadi Dan Pekon
STBM in the long term to reduce morbidity and mortality caused by poor sanitation. In addition, this program can encourage the creation of a healthy society that is independent and just. This is inseparable from the government's role in empowering its people regarding the importance of healthy living through sustainable development. The concept of sustainable development or sustainable development is not a concept that appears at one time, but is the result of a long debate process between the need for development and awareness of the importance of environmental protection. ${ }^{26}$

Basically, the function of the government in carrying out the construction consists of two functions: a) primary function or functions of the service, which the government serves as a provider of public services which can not be privatized services including civil and bureaucratic service; b) secondary function or empowerment function, namely as a provider of the needs and demands of the governed for goods and services that they are unable to fulfill on their own because

Kediri Kecamatan Gadingrejo)” (Skripsi, Universitas Lampung, 2019), 25.

${ }^{25}$ Muhammad Labolo, Memahami Ilmu Pemerintahan (Jakarta: PT RajaGrafindo Persada, 2010), 32.

${ }^{26}$ Andri G Wibisana, "Pembangunan Berkelanjutan: Status Hukum Dan Pemaknaannya," Jurnal Hukum \& Pembangunan Volume 43, no. 1. Januari-Maret (2013): 57. 
they are still weak and powerless, including the provision and construction of facilities and infrastructure. ${ }^{27}$

Behavior change in STBM is carried out through a triggering method that encourages changes in the behavior of the target community collectively and is able to build sanitation facilities independently according to their abilities, based on community participation. According to Jennifer-Mc Cracken-Deepa that participation is a process by which the parties involved influence and control development initiatives, decisions and sources that affect them. Participation has different sides, starting from providing information and consultation methods to mechanisms for collaboration and empowerment that provide opportunities for stakeholders to have more influence and control. ${ }^{28}$

The role of the Government in supporting the implementation of STBM is as follows: a) coordinating across sectors and programs; b) preparing technical training materials for trainers; c) conduct monitoring and evaluation; and d) conduct studies, research and development. Meanwhile, the provincial government has

\footnotetext{
27 Taliziduhu Ndraha, Kybernology (Ilmu Pemerintahan Baru) (Jakarta: Rineka Cipta, 2003), 76.

28 Chika Chaerunnissa, "Partisipasi Masyarakat Dalam Program Penyediaan Air Minum Dan Sanitasi Berbasis Masyarakat Di Kabupaten Brebes (Studi Kasus Desa Legok Dan Desa Tambakserang Kecamatan Bantarkawung)," Jurnal Politika Volume 5, no. 2. Oktober (2014): 3 .
}

the following roles: a) to coordinate across sectors and programs, networks and partnerships; b) carry out technical training for district / city trainers; c) carry out district / city monitoring and evaluation; d) determine the priority scale of district / city development in the application of STBM; and e) provide communication, information and educational media materials. Furthermore, the role of Regency / City Government to support the implementation of STBM is a) to determine the regional priority scale for the application of STBM; b) coordinate across sectors and programs, networks, and partnerships in the framework of developing STBM implementation; c) carry out technical training for officers and communities at sub-districts and / or villages / kelurahan; d) monitoring and evaluation; and e) provide communication, information and educational media materials. ${ }^{29}$ The role of the District Government, namely: first, coordinating across sectors, second, reporting. Meanwhile, the role of the Village Government is: first, cross-sector coordination, second, monitoring. ${ }^{30}$

\footnotetext{
29 Kementerian Kesehatan, Peraturan Menteri Kesehatan Republik Indonesia Nomor 3 Tahun 2014 Tentang Sanitasi Total Berbasis Masyarakat, Lihat Pasal 10, Pasal 11 dan Pasal 12.

30 Muaja, Pinontoan, and Sumampouw, "Peran Pemerintah Dalam Implementasi Program Sanitasi Total Berbasis Masyarakat Stop Buang Air Besar Sembarangan," 30.
} 
Based on the Circular of the Sambas Regent Number 440/16 / Dinkes concerning the Implementation of the STBM Program, one of the main activities in the STBM approach is to create a village that is free from open defecation. With regard to these efforts, all Camat in Sambas Regency should carry out the following steps: a) increase the number of villages implementing STBM; b) increasing the number of villages stop open defecation (SBS); c) optimizing the role of the District and Village in achieving areas free from open defecation; d) encourage the formation of STBM teams at the District and Village levels; e) encourage efforts to change people's behavior through health promotion media; f) increasing the STBM budget in the District APBD, Puskesmas BOK and including the STBM in the Village RPJM; g) utilizing the potential of local wisdom by encouraging mutual cooperation and community self-reliance in building family toilets in accordance with the non-subsidized principle in STBM; h) ensuring the prohibition of open defecation by making regulations in the form of Village Regulations; i) maximizing the synergy and integrity of the STBM approach with crosssectoral and cross-program activities related to efforts to reduce stunting rates; $j$ ) upgrading the status of verified SBS Village

31 Surat Edaran Bupati Sambas Nomor 440/16/Dinkes tentang Pelaksanaan Program Sanitasi Total Berbasis Masyarakat. to STBM Village through the development of 5 STBM pillars; k) optimize the role of the village government in the effort to reach the SBS Village to create a healthy village; 1) carry out regular monitoring of the development of STBM activities through website-based information technology and the SMS Gate Way (monev.stbm.kemkes.go.id). ${ }^{31}$

\section{ODF Village Government} Involvement In The Program

\section{Implementation STBM}

Open defecation free, which is an award given to Kartiasa Village, is a special spirit for the Village Government and the community to keep the environment clean so that it can avoid the dangers of various diseases. Kartiasa Village was named ODF Village on 28 April 2014 which is the beginning and challenge for the Village Government to maintain and improve the quality and title that this village bears. Various policies are made by the local government to provide support to the village government and the community in order to keep the environment in which they live clean.

The most influential role in maintaining environmental hygiene is the role of the Village Government, because the Village 
Government is closest to the community and has direct contact and can see the condition of the community directly. The role of the Village Government is influential in creating an atmosphere that encourages communities in the village to take steps to support the ODF program. Strategic steps in increasing public access to proper and sustainable sanitation through the implementation of the national STBM strategy as an approach to sanitation development in Indonesia.

One of the main activities in the STBM approach is to create a village that is free from open defecation. The achievement of ODF Village status is realized through the implementation of a comprehensive and integrated STBM approach with relevant stakeholders. Based on this, the Regional Government of Sambas Regency issued a Circular Letter of the Regent of Sambas Number 440/16/Dinkes concerning Implementation of Community-Based Total Sanitation Programs. In the context of Kartiasa Village as ODF Village, it is fitting to carry out this circular to the fullest.

Sambas Regent Circular Number 440/16 / Dinkes concerning Implementation of Community Based Total Sanitation Programs, contains several steps that must be implemented by the Village Government as a legal basis for the role of the village itself. As for the role of the Village Government according to the
Sambas Regent Circular Number 440/16 /

Dinkes concerning the Implementation of the Community-Based Total Sanitation Program, among others: 1) optimizing the role of the village in achieving areas free from open defecation ; 2) STBM is included in the Village RPJM; 3) Make a Village Regulation regarding stopping open defecation; 4) optimizing the role of the Village Government in the effort to reach the Village to stop open defecation to create a Healthy Village.

The researcher analysis is as follows:

a) Optimize the village's role in the achievement of the area that is free from open defecation behavior.

In this case, the village government Kartiasa awarded as ODF village or village free from people's behavior defecation on 28 April 2014. This means that measures achievement of defecation free area has been done by the village government Kartiasa.

b) STBM is included in the Village RPJM.

Based on the results of an interview with Mr. Abul Khair as the Secretary of Kartiasa Village, Mr. Dedi Nurfiansyah as Head of Administration and General Affairs, Mr. Iswandi as Head of Planning, and Mrs. Yulida as the Head of Service on August 13, 2020, said that the STBM program had been included in the Kartiasa Village Medium-Term Development Plan (RPJM) which contained 3 pillars, namely stopping 
open defecation, washing hands with soap, and household waste management. Based on this, it means that the steps contained in number 6 of Sambas Regent Circular Letter Number 440/16 / Dinkes concerning Implementation of Community-Based Total Sanitation Programs have been implemented.

c) Make a Village Regulation regarding stopping open defecation

The results of the interview on August 13, 2020 with the Kartiasa Village Apparatus, namely Mr. Abul Khair, Mr. Dedi Nurfiansyah, Mr. Iswandi, Mrs. Yulida said that until now the Kartiasa Village Government had no regulations in the form of a Kartiasa Village Regulation concerning the prohibition of open defecation. This shows that the Kartiasa Village Government has not carried out the mandate from the Regent of Sambas as contained in the Sambas Regent Circular Number 440/16 / Dinkes concerning Implementation of the Community-Based Total Sanitation Program, number 8.

d) optimizing the role of the Village Government in the effort to reach the Village to stop open defecation to create a Healthy Village.

Based on the author's observations, that there is a septic tank in a latrine located on the edge of the Sambas river, then the researcher conducted interviews with the Kartiasa Village Government and the community to clarify the origin of the saptic tank. The results revealed that the saptic tank was assistance from the Sambas Housing and Environmental Settlement Service. In addition, there are health promotion banners to educate the public about the importance of clean and healthy living habits. This shows that the Kartiasa Village Government has optimally provided facilities and education to the Kartiasa Village community which is part of a form of empowerment. Empowerment is a form of effort to provide strength, increase the abilities and potentials of individuals and groups of poor people to realize their potential and try to leave the previous underdeveloped state. Therefore, in the empowerment process it is very important for community participation to identify problems and potentials that exist in society.

But when seen in the behavioral aspects of the villagers Kartiasa still found people who defecation, so that shows the role of the village government is still not optimal for society's independence clean and healthy living behavior.

\section{Inhibiting Factors in Implementing Village Government ODF STBM Program}

Not whether human behavior will lead to changes in the ecosystem and the emergence of a number of community environment sanitation problems. Based on the results of the analysis of the role of the 
132 | Tamrin Muchsin dan Sri Sudono Saliro., Open Defecation Free in Kartiasa ,...pp. 121-134

Kartiasa Village Government in implementing open defecation free according to the Sambas Regent Circular Number 440/16 / Dinkes regarding the Implementation of the Community-Based Total Sanitation Program, the results of observations and the results of interviews conducted by researchers, there are still several obstacles, including:

a) Public legal awareness factor. Lack of public awareness of the importance of clean and healthy lifestyle behavior. This is evidenced in the results of interviews that there are still people's behavior that defecate in the open and do not reflect the behavior of a clean and healthy lifestyle, such as littering in rivers and others.

b) Public perception factors. The notion of people who think that the $\mathrm{BAB}$ in pit latrines or sewage directly into rivers without saptic tank, does not cause harm because dirt will dissolve in water.

c) Legal Factors. The point is that there is no formal legality in the form of the Kartiasa Village Regulation concerning the Prohibition of Open Defecation.

d) Facility and infrastructure factors. Limited facilities and infrastructure for building toilets or latrines around the banks of the Kartiasa river.

e) Supervision Factor. There is no supervision from the Village
Government on the behavior of open defecation, this is because there is no Village Regulation as the basic basis for implementing supervision.

\section{CONCLUSION}

Based on the statement and the results of the research findings, it can be concluded as follows: that the involvement of the Kartiasa Village government in implementing open defecation free is in the form of educational facilities for the community in the form of banners to maintain environmental cleanliness. So that the involvement is not optimal, because the community still behaves in open defecation, there is no village regulation that regulates the prohibition of open defecation in the river, and as a result of the absence of this village regulation, efforts to monitor the behavior of people who defecate in open defecation cannot be sanctioned. These various obstacles require the active and responsive role of the Kartiasa Village Government to formulate legal policy steps, such as the existence of a Village Regulation concerning the prohibition of open defecation, in addition, the Regional Government also provides full support for environmental issues, especially regarding river pollution.

\section{REFERENCES}

Ahmadi, Robby. "Analisis Peran Pemerintah Pekon Dalam Pelaksanaan Pilar Pertama Program 
Sanitasi Total Berbasis Masyarakat Di Kabupaten Pringsewu (Studi Di Pekon Wonodadi Dan Pekon Kediri Kecamatan Gadingrejo)." Skripsi, Universitas Lampung, 2019.

Arifianty, Della Putri. "Peran Pemerintah Lokal Dalam Peningkatan Sanitasi Lingkungan Masyarakat: Studi Tentang Keberhasilan Program Open Defecation Free (ODF) Di Kabupaten Bojonegoro." Jurnal Kebijakan Dan Manajemen Publik Volume 5, no. 3, SeptemberDesember (2017).

Celesta, Almas Ghassani, and Nurul Fitriyah. "Gambaran Sanitasi Dasar Di Desa Payaman, Kabupaten Bojonegoro Tahun 2016." Jurnal Kesehatan Lingkungan Volume 11, no. 2. April (2019). doi:10.20473/jkl.v11i2.2019.83-90.

Chaerunnissa, Chika. "Partisipasi Masyarakat Dalam Program Penyediaan Air Minum Dan Sanitasi Berbasis Masyarakat Di Kabupaten Brebes (Studi Kasus Desa Legok Dan Desa Tambakserang Kecamatan Bantarkawung)." Jurnal Politika Volume 5, no. 2. Oktober (2014).

Dewi, Yusriani Sapta. "Peran Perempuan Dalam Pembangunan Berkelanjutan." Jurnal Pendidikan Lingkungan Dan Pembangunan Berkelanjutan Vol. XII No. 02 (2011): 61-64.

Ditjen Kesehatan Masyarakat, Kementerian Kesehatan. Kebijakan Nasional Sanitasi Total Berbasis Masyarakat (STBM). Jakarta: Disampaikan dalam Lokakarya Review STBM pada 24 Januari, 2019.

Floridiana, Zamia. "Analisis Higiene Penjamah Makanan Dan Sanitasi Lingkungan Pada Industri Rumah Tangga Tahu Jombang 2018." Jurnal Kesehatan Lingkungan Volume 11, no.
1. Januari
doi:10.20473/jkl.v11i1.2019.75-82.

Hoelman, Mickael B, and Sugeng Bahagijo, dkk. Sustainable Development GoalsSDGs Panduan Untuk Pemerintah Daerah Kabupaten/Kota Dan Pemangku Kepentingan Daerah). Jakarta Selatan: INFID Edisi Revisi, 2016.

Kementerian Kesehatan. Peraturan Menteri Kesehatan Republik Indonesia Nomor 3 Tahun 2014 Tentang Sanitasi Total Berbasis Masyarakat (2014).

Labolo, Muhammad. Memabami Ilmu Pemerintahan. Jakarta: PT RajaGrafindo Persada, 2010.

Mardikanto, and Poerwoko. Pemberdayaan Masyarakat Dalam Perspektif Kebijakan Publik. Bandung: Alfabeta, 2015.

Muaja, Maria Sophie, Odi Roni Pinontoan, and Oksfriani Jufri Sumampouw. "Peran Pemerintah Dalam Implementasi Program Sanitasi Total Berbasis Masyarakat Stop Buang Air Besar Sembarangan." Indonesian Journal of Public Health and Community Medicine Volume 1, no. 3 (July 2020).

Mudzhar, M Atho. Pendekatan Studi Islam Dalam Teori Dan Praktek. Yogyakarta: Pustaka Pelajar, 1998.

Ndraha, Taliziduhu. Kybernology (Imu Pemerintahan Baru). Jakarta: Rineka Cipta, 2003.

Norman K. Denzin, Yvonna S. Lincoln (editor), and Dariyatno (penerjemah). Handbook of Qualitative Research (Edisi Ketiga). Yogyakarta: Pustaka Pelajar, 2009.

Rosana, Mira. "Kebijakan Pembangunan Berkelanjutan Yang Berwawasan Lingkungan Di Indonesia." Jurnal KELOLA: Jurnal Ilmu Sosial Vol. 1 No. 1 (2018): 148-63. 
Sekretariat Jenderal MPR RI 2018. UndangUndang Dasar Negara Republik Indonesia Tahun 1945 (2018).

Setyaningsih, Tatiek, and Bayu Mitra Adhyatma Kusuma. "Mendobrak Keterbatasan Masyarakat: Mewujudkan Desa Open Defecate Free Di Kabupaten Banyuwangi Melalui Inovasi 'Pujasera."' The Indonesian Journal of Public Administration Volume 2, no. 2 (Nopember 2016).

Sjafrizal. Perencanaan Pembangunan Daerah Dalam Era Otonomi. Jakarta: PT RajaGrafindo Persada, 2014.

Sukma, Hadiati, Mursid, and Nurjazuli. "Hubungan Pengetahuan, Sikap BAB, Dan Kepemilikan Septic Tank Dengan Status ODF (Open Defecation Free) Di Kecamatan Candisari Kota Semarang." Jurnal Kesehatan Masyarakat Volume 6, no. Nomor 6, Oktober (2018): pp 143149.

Surat Edaran Bupati Sambas Nomor 440/16/Dinkes tentang Pelaksanaan Program Sanitasi Total Berbasis Masyarakat (2018).

UCLG. "UCLG and Global Taskforce Advocacy Pays off in SDGs Outcome Document 'Transforming Our World'. Http://Www.Uclg.Org/En/Media/ News/Uclg-and-GlobalTaskforce-Advocacy-Pays-SDGsOutcome-DocumentTransforming-Our-World.," n.d.

Wawancara dengan Bapak Abul Khair selaku Sekretaris Desa Kartiasa, tanggal 13 Agustus, 2020.

Wawancara dengan Bapak Dedi Nurfiansyah selaku Kaur Tata Usaha dan Umum Desa Kartiasa, 13 Agustus, 2020.
Wawancara dengan Bapak Edy Rakhman selaku Kepala Desa Kartiasa, tanggal 2 Juli, 2020.

Wawancara dengan Bapak Iswandi selaku Kaur Perencanaan Desa Kartiasa, 13 Agustus, 2020.

Wawancara dengan Ibu Yulida selaku Kasi Pelayanan Desa Kartiasa, 13 Agustus, 2020.

Wibisana, Andri G. "Pembangunan Berkelanjutan: Status Hukum Dan Pemaknaannya." Jurnal Hukum \& Pembangunan Volume 43, no. 1. Januari-Maret (2013). 